Article

\title{
Cytotoxic Polyhydroxysteroidal Glycosides from Starfish Culcita novaeguineae
}

\author{
Yunyang Lu ${ }^{1}, \mathrm{Hu} \mathrm{Li}^{1,2}{ }^{,}$Minchang Wang ${ }^{3}$, Yang Liu ${ }^{1}$, Yingda Feng ${ }^{1}, \mathrm{Ke} \mathrm{Liu}^{3}$ \\ and Haifeng Tang 1 ,* \\ 1 Institute of Materia Medica, School of Pharmacy, Fourth Military Medical University, Xi'an 710032, China; \\ luyunyanggq@163.com (Y.L.); pharm_lihu@163.com (H.L.); so870823@163.com (Y.L.); \\ fyd1991@sina.com (Y.F.) \\ 2 First Motorized Detachment of Shanghai Armed Police Corps, Shanghai 200126, China \\ 3 Nuclear Magnetic Resonance Center, Xi'an Modern Chemistry Research Institute, Xi'an 710065, China; \\ wmc204@163.com (M.W.); happycoco5133@163.com (K.L.) \\ * Correspondence: tanghaifeng71@163.com; Tel.: +86-29-8477-4748
}

Received: 7 February 2018; Accepted: 10 March 2018; Published: 13 March 2018

\begin{abstract}
Four new polyhydroxysteroidal glycosides—culcinosides A-D (1, 2, 4, and 7)—along with three known compounds-echinasteroside C (3), linckoside F (5), and linckoside L3 (6) -were isolated from the ethanol extract of starfish Culcita novaeguineae collected from the Xisha Islands of the South China Sea. The structures of new compounds were elucidated through extensive spectroscopic studies and chemical evidence, especially two-dimensional (2D) NMR techniques. The cytotoxicity of the new compounds against human glioblastoma cell lines U87, U251, and SHG44 were evaluated.
\end{abstract}

Keywords: Culcita novaeguineae; starfish; polyhydroxysteroidal glycoside; cytotoxicity

\section{Introduction}

The starfish is a sea animal belonging to Asteroidea: Echinodermata that is distributed worldwide; there are approximately 1900 species grouped into 370 genera [1]. Steroidal glycosides are the predominant metabolites of starfish, and are responsible for their general toxicity. Based on structural characteristics, they have been subdivided into three groups: asterosaponins, polyhydroxysteroidal glycosides, and cyclic steroidal glycosides [2]. Polyhydroxysteroidal glycosides are abundant in the metabolism of starfish; more than 500 have been identified in total [3]. In general, polyhydroxysteroidal glycosides consist of an oxygenated steroidal aglycone with more than three hydroxy groups, and one or two (rarely three) monosaccharide residues attached to the steroidal nucleus or side chain. Polyhydroxysteroidal glycosides have been reported to show a broad spectrum of biological activities, including hemolytic, cytotoxic, immunoregulatory, anti-bacterial, neuritogenic, anti-inflammatory, and anti-biofouling effects [4-12]. Culcita novaeguineae is plentiful in the South China Sea; it is used as a folk medicine for the treatment of rheumatism, and as a tonic in China [13]. The chemical constituent investigation of this starfish has led to the isolation of several polyhydroxysteroid glycosides and asterosaponins by scientists around the world $[14,15]$. The previous work that our team carried out on Culcita novaeguineae led to the isolation of a series of novel asterosaponins. Some of these have shown significant cytotoxicity against several human cancer cell lines, such as asterosaponin 1 , through suppressing the proliferation of human glioblastoma cell line U87 with an $\mathrm{IC}_{50}$ of $4.3 \mathrm{\mu g} / \mathrm{mL}[2,6,16-19]$. However, no polyhydroxysteroidal glycosides, as a large class of bioactive metabolites of starfish, were found in our previous work. Therefore, as part of a continuous search for bioactive steroidal glycosides from starfish, we aimed for the polyhydroxysteroidal glycosides in Culcita novaeguineae. Herein, we report the isolation, structural elucidation, and biological activity screening of four new polyhydroxysteroidal glycosides, culcinosides A-D $(1,2,4$, and 7), together with three 
known compounds, which were identified as echinasteroside C (3), linckoside F (5), and linckoside L3 (6), through a comparison of the physical and spectra data with literature values (Figure 1) $[10,12,20]$.
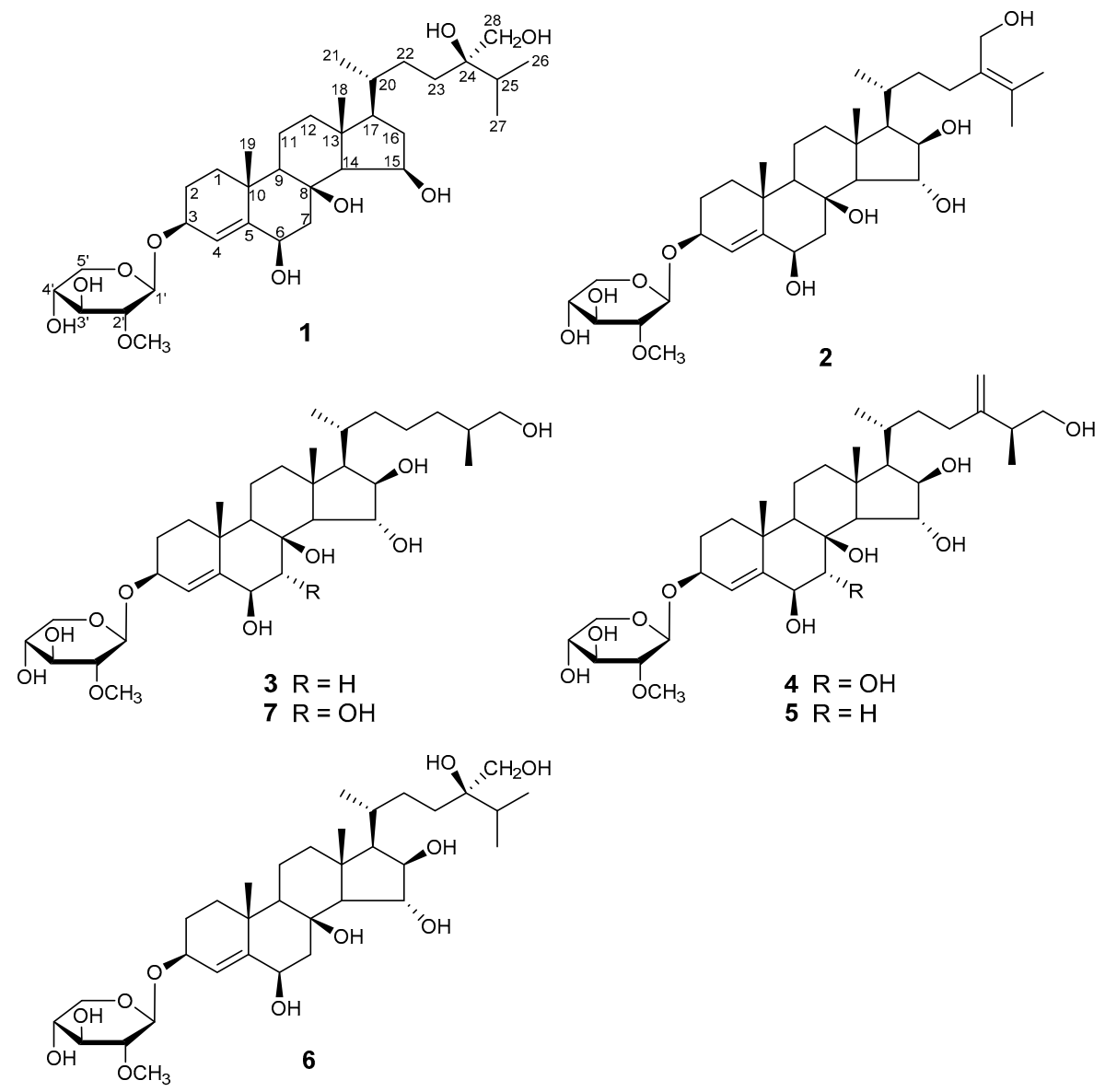

Figure 1. The structures of compounds 1-7 isolated from starfish Culcita novaeguineae.

\section{Results and Discussion}

\subsection{Structure Elucidation}

Culcinoside A (1) was isolated as a colorless powder, and was positive for the Liebermann-Burchard and Molisch tests, which indicated that it might be a steroidal glycoside. The molecular formula of compound 1 was determined as $\mathrm{C}_{34} \mathrm{H}_{58} \mathrm{O}_{10}$ by ESIMS at $m / z 649[\mathrm{M}+\mathrm{Na}]^{+}$

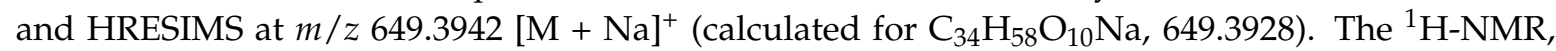
${ }^{13} \mathrm{C}-\mathrm{NMR}$, and DEPT spectra suggested the existence of a trisubstituted double bond $\left(\delta_{\mathrm{C}} 126.5\right.$, $\delta_{\mathrm{H}}$ 5.94; $\left.\delta_{\mathrm{C}} 148.9\right)$, two angular methyls $\left(\delta_{\mathrm{C}} 16.0, \mathrm{C}-18 ; \delta_{\mathrm{C}} 23.1, \mathrm{C}-19\right)$ with singlets $\left(\delta_{\mathrm{H}} 1.30, \mathrm{H}-18\right.$; $\left.\delta_{\mathrm{H}} 1.66, \mathrm{H}-19\right)$, three doublets $\left(\delta_{\mathrm{H}} 1.07, \delta_{\mathrm{C}} 19.4, \mathrm{C}-21 ; \delta_{\mathrm{H}} 1.22, \delta_{\mathrm{C}} 18.0, \mathrm{C}-26 ; \delta_{\mathrm{H}} 1.20, \delta_{\mathrm{C}} 18.1, \mathrm{C}-27\right)$, three oxidized methines $\left(\delta_{\mathrm{C}} 69.5, \delta_{\mathrm{H}} 4.90 ; \delta_{\mathrm{C}} 75.9, \delta_{\mathrm{H}} 4.77 ; \delta_{\mathrm{C}} 76.6, \delta_{\mathrm{H}} 4.48\right)$, and two oxygenated quaternary carbon $\left(\delta_{C} 76.0, \delta_{C} 76.2\right)$. A comprehensive analysis and comparison of the above data with that of co-isolated linckoside L3 (6) indicated that they may share the same steroidal aglycone and side chain (Table 1). A difference was recognized in ring D, where a secondary alcohol $\left(\delta_{\mathrm{C}} 83.1, \delta_{\mathrm{H}} 4.04\right)$ in compound 6 was replaced by one methylene $\left(\delta_{\mathrm{H}} 2.15\right.$ and $\left.2.27, \delta_{\mathrm{C}} 42.3, \mathrm{CH}_{2}-16\right)$ of compound 1. Furthermore, this substitution was witnessed by the upfield shift of $C-15\left(\delta_{C} 69.5, \delta_{H} 4.90\right)$ in compound 1 when compared with that of $6\left(\delta_{C} 80.6, \delta_{H} 4.17\right)$. The position of the double bond was determined by HMBC correlations for H-4 to C-2, C-6, and C-10; H-3 and H-5 to C-4 and C-5; and $\mathrm{H}-19$ to $\mathrm{C}-5$. This connection was further confirmed by the ${ }^{1} \mathrm{H}-{ }^{1} \mathrm{H}$ COSY correlations for $\mathrm{H}-3$ to H-4. The assignment of the NMR signals associated with the aglycone moiety and side chain 
(Table 1) was derived from HSQC, ${ }^{1} \mathrm{H}_{-}{ }^{1} \mathrm{H}$ COSY, HMBC, and TOCSY experiments. The normally occurring 2-O-methyl- $\beta$-D-xylopyranose (2-OMe-Xyl) moiety in the polyhydroxysteroidal glycosides was detected in compound 1 by analyzing the one-dimensional (1D) and two-dimensional (2D) NMR spectra, and by comparing the monosaccharide signals with those co-isolated known compounds and the literature values [21-23]. This was further confirmed by the demethylation and acid hydrolysis of compound 1 with $2 \mathrm{M}$ trifluoroacetic acid, followed by derivatization with 1-(trimethylsily)-imidazole, gas chromatography (GC) analysis sequentially, and a comparison with the corresponding derivatives of a standard monosaccharide $[6,8]$. The attachment of the monosaccharide to $\mathrm{C}-3$ was confirmed by HMBC correlation for $\mathrm{H}-3$ to $\mathrm{C}-1^{\prime}\left(\delta_{\mathrm{C}} 104.8\right)$ of the Xyl, and $\mathrm{H}-1^{\prime}\left(\delta_{\mathrm{H}} 4.84\right)$ of the Xyl to C-3 of the aglycone (Figure 2). The NOESY correlations of $\mathrm{H}-3$ to $\mathrm{H}-1 \mathrm{~b}, \mathrm{H}-1 \mathrm{~b}$ to $\mathrm{H}-9, \mathrm{H}-6$ to $\mathrm{H}-7 \mathrm{~b}$, and $\mathrm{H}-7 \mathrm{~b}$ to H-9, and the lack of correlation between $\mathrm{H}-1$ and $\mathrm{H}-6$ indicated the $\alpha$-orientation of $\mathrm{H}-3$ and H-6 (Figure 3 ). The $\beta$-orientation of the hydroxy at C-15 was determined by the NOESY correlation of H-16b to H-15 and $\mathrm{H}-17$, and the lack of correlation between $\mathrm{H}-14$ and $\mathrm{H}-15$. The $20 \mathrm{R}$ configuration was deduced from the NOESY correlation of $\mathrm{H}-20$ to $\mathrm{H}-18$, and the large coupling constant of $\mathrm{H}-17(\mathrm{~J}=9.1)$ [10]. It has been reported that small but important differences in the signals for the $\mathrm{HC}(28), \mathrm{H}^{\prime} \mathrm{C}(28)$, and $\mathrm{C}(28)$ atoms in the NMR spectra of the synthetic $24 R$ and $24 S$ epimers of 24-hydroxymethyl-24-hydroxycholesterol (24R: $\Delta \delta_{\mathrm{H}}=0.04, \delta_{\mathrm{C}}=66.0 ; 24 S: \Delta \delta_{\mathrm{H}}=0.06, \delta_{\mathrm{C}}=66.3$ ) [12]. The NMR spectroscopic data of compound 1 at $\mathrm{CH}_{2}-28\left(\Delta \delta_{\mathrm{H}}=0.04, \delta_{\mathrm{C}}=66.1\right)$ coincided with that of the $24 R$ epimer. Thus, the absolute configuration of $C-24$ was determined as $R$. Therefore, the structure of compound $\mathbf{1}$ was established as (24R)-3-O-(2-O-methyl- $\beta$-D-xylopyranosyl)-cholesta-4-ene-3 $\beta, 6 \beta, 8,15 \beta, 24,28$-hexaol.

Table 1. The ${ }^{1} \mathrm{H}-\mathrm{NMR}$ and ${ }^{13} \mathrm{C}-\mathrm{NMR}$ data of compounds $\mathbf{1}, \mathbf{2}, \mathbf{4}$, and 7 ( $\delta$ in ppm, $J$ in $\mathrm{Hz}$ ).

\begin{tabular}{|c|c|c|c|c|c|c|c|c|}
\hline \multirow{2}{*}{ Position } & \multicolumn{2}{|r|}{$1^{\mathrm{c}, \mathrm{e}}$} & \multicolumn{2}{|r|}{$2^{d, e}$} & \multicolumn{2}{|r|}{$4^{c, f}$} & \multicolumn{2}{|r|}{$7^{c, e}$} \\
\hline & $\delta_{C}$ & $\delta_{H}$ & $\delta_{C}$ & $\mathcal{\delta}_{\mathrm{H}}$ & $\delta_{C}$ & $\delta_{H}$ & $\delta_{C}$ & $\delta_{H}$ \\
\hline $1 \mathrm{a}$ & \multirow{2}{*}{39.4} & $1.85 \mathrm{~m}$ & \multirow{2}{*}{39.4} & $1.86 \mathrm{~m}$ & \multirow{2}{*}{39.6} & $1.77 \mathrm{~m}$ & \multirow{2}{*}{39.4} & $1.90 \mathrm{~m}$ \\
\hline $1 b$ & & $1.39 \mathrm{~m}$ & & $1.40 \mathrm{~m}$ & & $1.32 \mathrm{~m}$ & & $1.57 \mathrm{~m}$ \\
\hline $2 a$ & \multirow{2}{*}{28.2} & $2.28 \mathrm{~m}$ & \multirow{2}{*}{28.2} & $2.28 \mathrm{~m}$ & \multirow{2}{*}{28} & $1.99 \mathrm{~m}$ & \multirow{2}{*}{28.3} & $2.28 \mathrm{~m}$ \\
\hline $2 b$ & & $2.09 \mathrm{~m}$ & & $2.09 \mathrm{~m}$ & & $1.76 \mathrm{~m}$ & & $2.12 \mathrm{~m}$ \\
\hline 3 & 76.6 & 4.48 brt $(7.2)$ & 76.7 & $4.48 \mathrm{~m}$ & 77.5 & 4.24 brt $(8.2)$ & 76.6 & $4.51 \mathrm{~m}$ \\
\hline 4 & 126.5 & $5.94 \mathrm{~s}$ & 126.5 & $5.94 \mathrm{~s}$ & 130.3 & $5.70 \mathrm{~s}$ & 129.8 & $6.17 \mathrm{~s}$ \\
\hline 5 & 148.9 & - & 149 & - & 145.4 & - & 146.2 & - \\
\hline 6 & 75.9 & $4.77 \mathrm{~d}(2.5)$ & 76 & $4.76 \mathrm{~d}(2.3)$ & 79.9 & $4.12 \mathrm{~d}(3.1)$ & 80 & $4.87 \mathrm{~d}(2.7)$ \\
\hline $7 a$ & \multirow{2}{*}{44.9} & $3.40 \mathrm{dd}(14.8,2.5)$ & \multirow{2}{*}{44.9} & 3.49 dd $(14.7,2.3)$ & \multirow{2}{*}{73.9} & \multirow{2}{*}{$3.96 \mathrm{~d}(3.1)$} & \multirow{2}{*}{74.5} & \multirow{2}{*}{$4.84 \mathrm{~d}(2.7)$} \\
\hline $7 \mathrm{~b}$ & & $2.07 \mathrm{~m}$ & & $2.08 \mathrm{~m}$ & & & & \\
\hline 8 & 76 & - & 76 & - & 78 & - & 78.1 & - \\
\hline 9 & 57.6 & $1.24 \mathrm{~m}$ & 60.8 & $1.55 \mathrm{~m}$ & 51.5 & $1.34 \mathrm{~m}$ & 51.3 & $1.91 \mathrm{~m}$ \\
\hline 10 & 37.6 & - & 37.7 & - & 37.4 & - & 37.3 & - \\
\hline $11 \mathrm{a}$ & \multirow{2}{*}{19.7} & $2.10 \mathrm{~m}$ & \multirow{2}{*}{19.6} & $2.15 \mathrm{~m}$ & \multirow{2}{*}{19.4} & $1.89 \mathrm{~m}$ & \multirow{2}{*}{19.5} & $2.27 \mathrm{~m}$ \\
\hline $11 b$ & & $1.55 \mathrm{~m}$ & & $1.57 \mathrm{~m}$ & & $1.53 \mathrm{~m}$ & & $1.67 \mathrm{~m}$ \\
\hline $12 \mathrm{a}$ & \multirow[b]{2}{*}{42.5} & $2.07 \mathrm{~m}$ & \multirow{2}{*}{43} & $2.14 \mathrm{~m}$ & \multirow{2}{*}{43.1} & $1.98 \mathrm{~m}$ & \multirow[b]{2}{*}{43} & $2.16 \mathrm{~m}$ \\
\hline $12 b$ & & $1.28 \mathrm{~m}$ & & $1.32 \mathrm{~m}$ & & $1.22 \mathrm{~m}$ & & $1.40 \mathrm{~m}$ \\
\hline 13 & 45 & - & 45 & - & 45.5 & - & 45.3 & - \\
\hline 14 & 66.6 & $1.56 \mathrm{~m}$ & 64.1 & $1.51 \mathrm{~m}$ & 59.5 & $1.42 \mathrm{~d}(10.6)$ & 59.7 & $2.05 \mathrm{~d}(10.5)$ \\
\hline 15 & 69.5 & $4.90 \mathrm{~m}$ & 80.8 & $5.08 \mathrm{~m}$ & 80.1 & $4.20 \mathrm{dd}(10.6,1.8)$ & 80.4 & 5.11 brd (10.5) \\
\hline $16 a$ & 423 & $2.27 \mathrm{~m}$ & & & & & & (1) 72 dd (71 12 \\
\hline $16 b$ & 42.3 & $2.15 \mathrm{~m}$ & 83 & $4.78 \mathrm{~m}$ & 82.6 & $4.03 \mathrm{dd}(7.4,1.8)$ & 82.5 & $4.72 \mathrm{dd}(7.1,1.2)$ \\
\hline 17 & 55.8 & 1.61 brd (9.1) & 60.8 & $1.55 \mathrm{~m}$ & 61.4 & $1.29 \mathrm{dd}(10.8,7.4)$ & 61.6 & $1.54 \mathrm{~m}$ \\
\hline 18 & 16 & $1.30 \mathrm{~s}$ & 17.5 & $1.74 \mathrm{~s}$ & 17 & $1.16 \mathrm{~s}$ & 17.6 & $1.77 \mathrm{~s}$ \\
\hline 19 & 23.1 & $1.66 \mathrm{~s}$ & 23.1 & $1.67 \mathrm{~s}$ & 23.2 & $1.34 \mathrm{~s}$ & 23.6 & $1.68 \mathrm{~s}$ \\
\hline 20 & 36.6 & $1.54 \mathrm{~m}$ & 30.6 & $2.42 \mathrm{~m}$ & 30.7 & $1.90 \mathrm{~m}$ & 30.5 & $2.40 \mathrm{~m}$ \\
\hline 21 & 19.4 & $1.07 \mathrm{~d}(6.2)$ & 19.1 & $1.21 \mathrm{~d}(6.7)$ & 18.5 & $0.96 \mathrm{~d}(6.7)$ & 18.8 & $1.14 \mathrm{~d}(6.7)$ \\
\hline $22 a$ & & $1.92 \mathrm{~m}$ & & $2.20 \mathrm{~m}$ & & $1.74 \mathrm{~m}$ & & $1.96 \mathrm{~m}$ \\
\hline $22 \mathrm{~b}$ & 30.6 & $1.41 \mathrm{~m}$ & 35.7 & $1.54 \mathrm{~m}$ & 35.4 & $1.23 \mathrm{~m}$ & 37.1 & $1.33 \mathrm{~m}$ \\
\hline $23 a$ & 32 & $2.03 \mathrm{~m}$ & 292 & $2.55 \mathrm{t}(7.3)$ & & $2.15 \mathrm{~m}$ & 25 & $1.69 \mathrm{~m}$ \\
\hline $23 b$ & 32 & $1.85 \mathrm{~m}$ & 29.2 & $1.52 \mathrm{~m}$ & 33 & $1.97 \mathrm{~m}$ & 20 & $1.44 \mathrm{~m}$ \\
\hline $24 a$ & & - & & - & & - & & $1.64 \mathrm{~m}$ \\
\hline $24 b$ & 76.2 & - & 135 & - & 154 & - & $3 b$ & $1.23 \mathrm{~m}$ \\
\hline
\end{tabular}


Table 1. Cont.

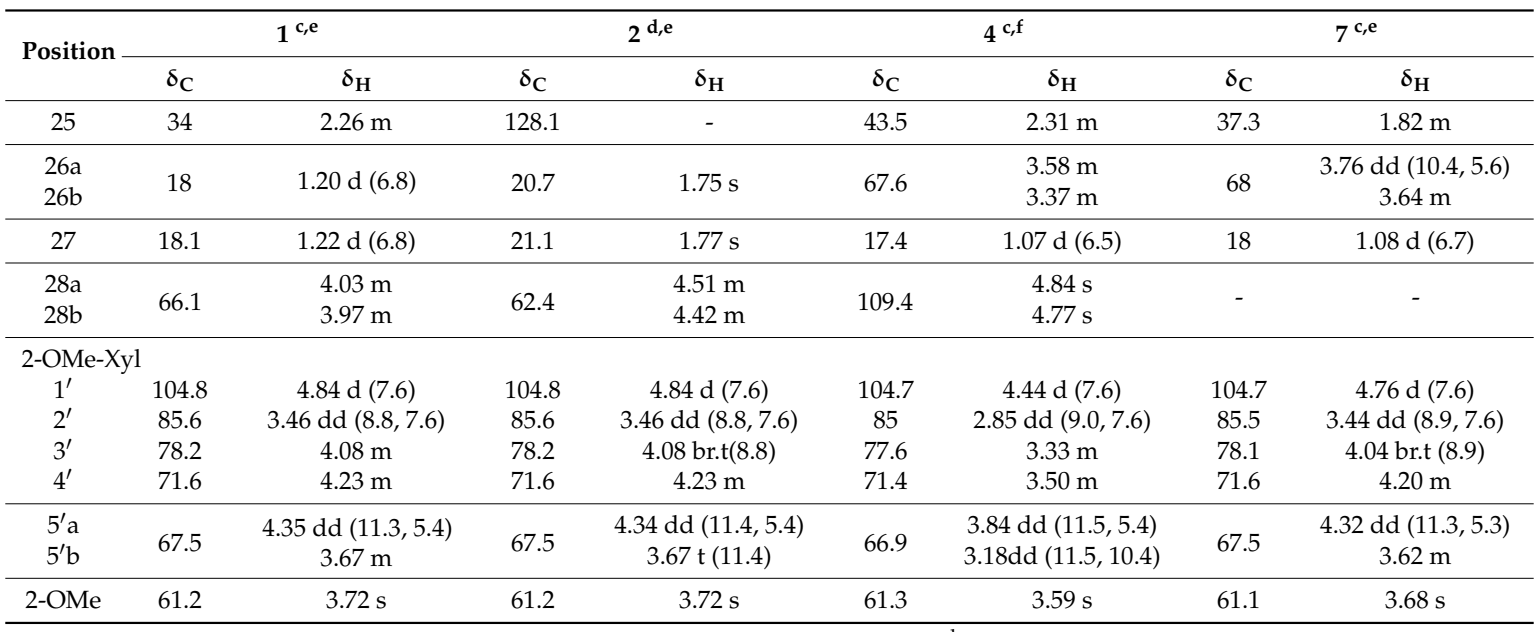

${ }^{\mathrm{c}}$ The NMR data were recorded at $500 \mathrm{MHz}$ for $\delta_{\mathrm{H}}$ and $125 \mathrm{MHz}$ for $\delta_{\mathrm{C}}{ }^{\mathrm{d}}{ }^{\mathrm{d}}$ the NMR data were recorded at $800 \mathrm{MHz}$ for $\delta_{\mathrm{H}}$ and $200 \mathrm{MHz}$ for $\delta_{\mathrm{C}} ;{ }^{\mathrm{e}}$ in $\mathrm{C}_{5} \mathrm{D}_{5} \mathrm{~N} ;{ }^{\mathrm{f}}$ in $\mathrm{CD}_{3} \mathrm{OD}$.
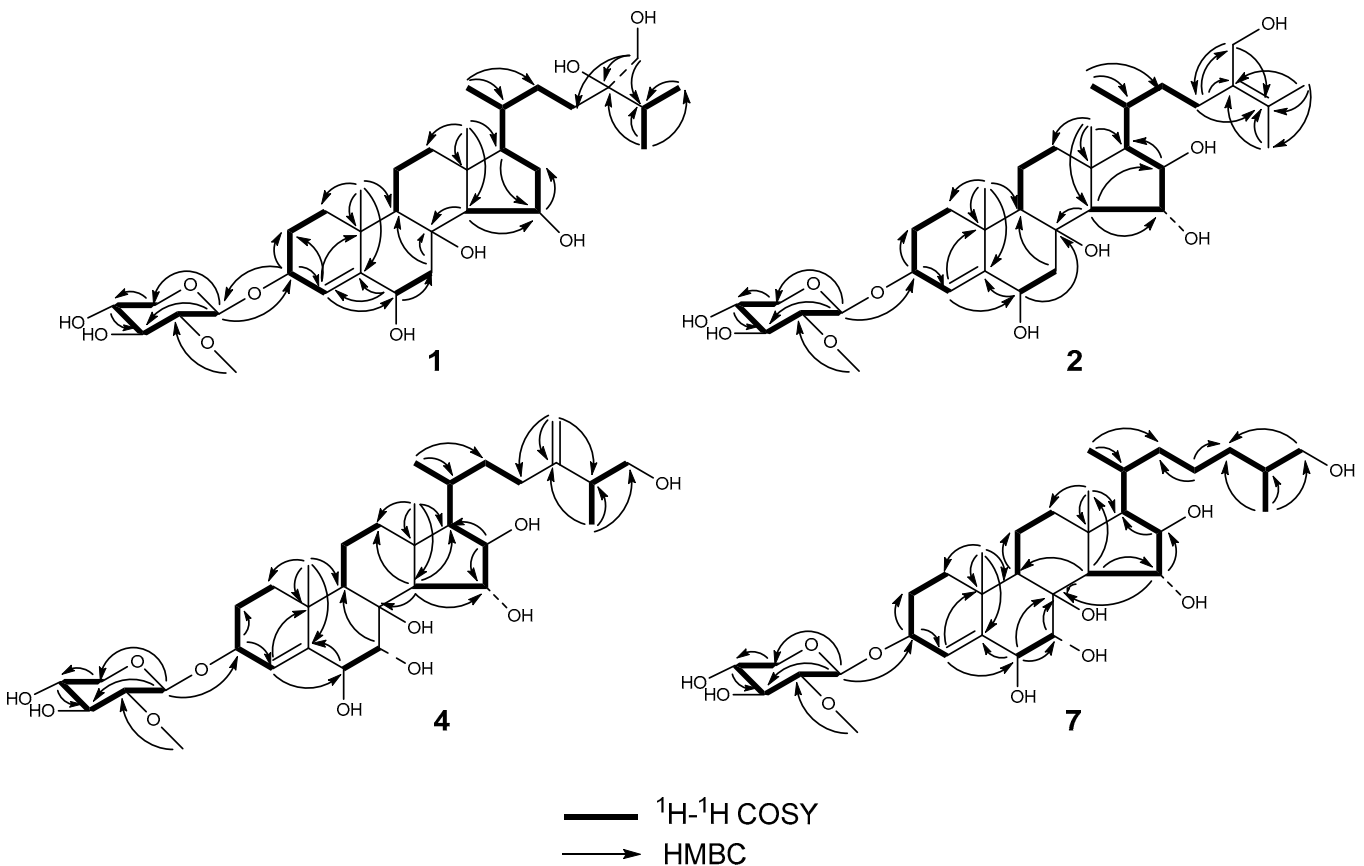

Figure 2. The key ${ }^{1} \mathrm{H}^{-1} \mathrm{H}$ COSY and HMBC correlations of the new compounds culcinosides A-D $(1,2,4$, and 7).

Culcinoside B (2), a colorless powder, was positive for the Liebermann-Burchard and Molisch tests, which indicated that it might be a steroidal glycoside. The molecular formula of compound 2 $\left(\mathrm{C}_{34} \mathrm{H}_{56} \mathrm{O}_{10}\right)$ was deduced from HRESIMS at $m / z$ 647.3795 [M $\left.+\mathrm{Na}\right]^{+}$(calculated for $\mathrm{C}_{34} \mathrm{H}_{56} \mathrm{O}_{10} \mathrm{Na}$, 647.3771). The ${ }^{1} \mathrm{H},{ }^{13} \mathrm{C}$, and DEPT NMR spectra signals belonging to the tetracyclic moiety of the aglycone of compound 2 revealed the presence of two angular methyls $\left(\delta_{\mathrm{C}} 17.5, \delta_{\mathrm{H}} 1.74 \mathrm{~s}\right.$, $\left.\mathrm{CH}_{3}-18 ; \delta_{\mathrm{C}} 23.1, \delta_{\mathrm{H}} 1.67 \mathrm{~s}, \mathrm{CH}_{3}-19\right)$, one trisubstituted double bond $4(5)\left(\delta_{\mathrm{C}} 126.5, \delta_{\mathrm{H}} 5.94, \mathrm{C}-4\right.$; $\delta_{\mathrm{C}}$ 149.0, C-5), three oxygenated methines $\left(\delta_{\mathrm{C}} 76.0, \delta_{\mathrm{H}} 4.76, \mathrm{CH}-6 ; \delta_{\mathrm{C}} 80.8, \delta_{\mathrm{H}} 5.08, \mathrm{CH}-15\right.$; $\delta_{\mathrm{C}}$ 83.0, $\left.\delta_{\mathrm{H}} 4.78, \mathrm{CH}-16\right)$, one oxygenated methine ( $\left.\mathrm{CH}-3\right)$ bearing a monosaccharide residue $\left(\delta_{\mathrm{C}} 76.7, \delta_{\mathrm{H}} 4.48\right)$, and one quaternary oxygenated carbon $\mathrm{C}-8\left(\delta_{\mathrm{C}} 76.0\right)$. All of the above data were similar to the known compounds echinasteroside $C(3)$ and linckoside $A$, which possessed the same $\Delta^{4}-3 \beta, 6 \beta, 8,15 \alpha, 16 \beta$-pentahydroxycholestane aglycone $[11,20]$. The chemical shift of the 
anomeric proton at $\delta_{\mathrm{H}} 4.84(\mathrm{~J}=7.6)$ associated with the anomeric carbon at $\delta_{\mathrm{C}} 104.8$ in the HSQC spectrum and the carbon signals at $\delta_{C} 61.2,67.5,71.6,78.16$, and 85.6 suggested the presence of the 2-O-methyl- $\beta$-D-xylopyranose monosaccharide residue, and this was further confirmed by acid hydrolysis followed by GC analysis. The connection of the monosaccharide to C-3 was deduced from the HMBC correlation for $\mathrm{H}-1^{\prime}$ of $\mathrm{Xyl}$ to $\mathrm{C}-3$ of the aglycone (Figure 2). All of the $\mathrm{H}$ and $\mathrm{C}$ signals of compound 2 were assigned by the $2 \mathrm{D}$ NMR spectra, including $\mathrm{HSQC},{ }^{1} \mathrm{H}^{1} \mathrm{H}$ COSY, and HMBC (Table 1). The structure of the side chain for compound 2 was elucidated on the basis of 2D NMR spectra. The tetrasubstituted double bond at C-24 and C-25, and the C-28 hydroxymethyl were determined by HMBC correlations for $\mathrm{H}-23(2 \mathrm{H})$ to $\mathrm{C}-24, \mathrm{C}-25$ and C-28; $\mathrm{H}-26$ and $\mathrm{H}-27$ to C-24 and C-25; and H-28 (2H) to C-23, C-24, and C-25. The $3 \beta, 6 \beta, 15 \alpha$, and $16 \beta$ orientations for the aglycone of 2 were confirmed by the cross-peaks of the NOESY spectrum (Figure 3). The 20R configuration was deduced from the NOESY correlation of $\mathrm{H}-20$ to $\mathrm{H}-18$, and $\mathrm{H} \alpha-13$ to $\mathrm{H}-21$. According to the data above, the structure of compound 2 was elucidated as 3-O-(2-O-methyl- $\beta$-D-xylopyranosyl)-cholesta-4,24-diene-3 $\beta, 6 \beta, 8,15 \alpha, 16 \beta, 28$-hexaol.

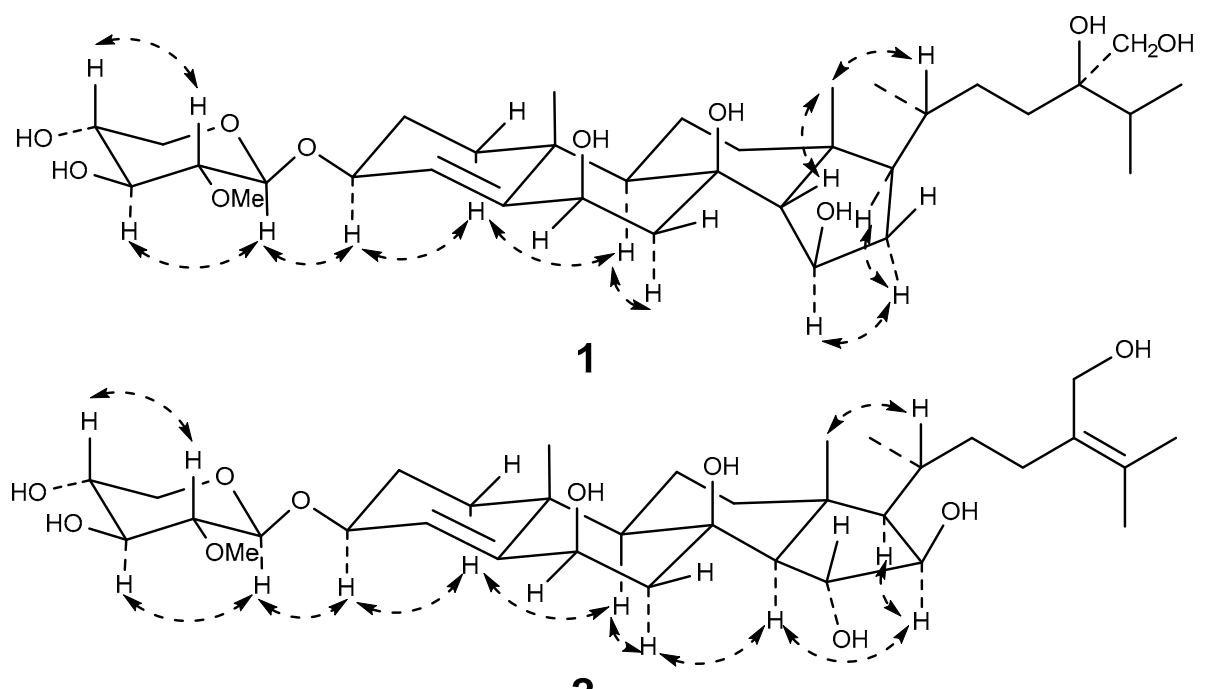

2

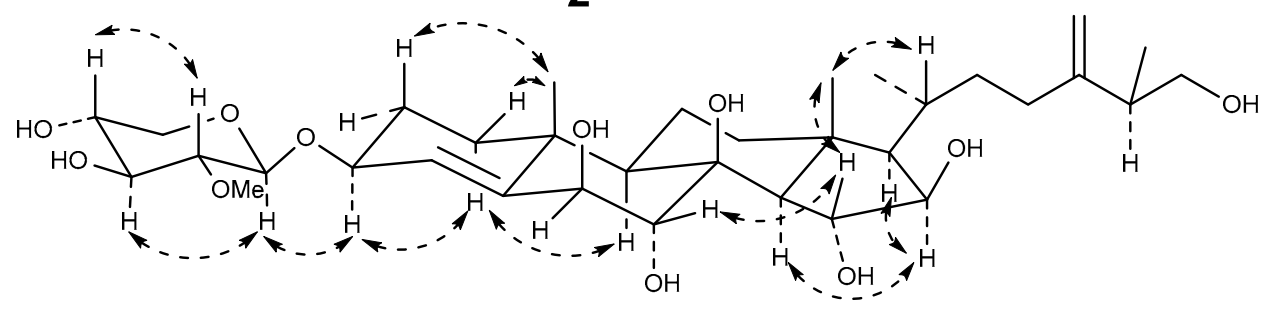

4

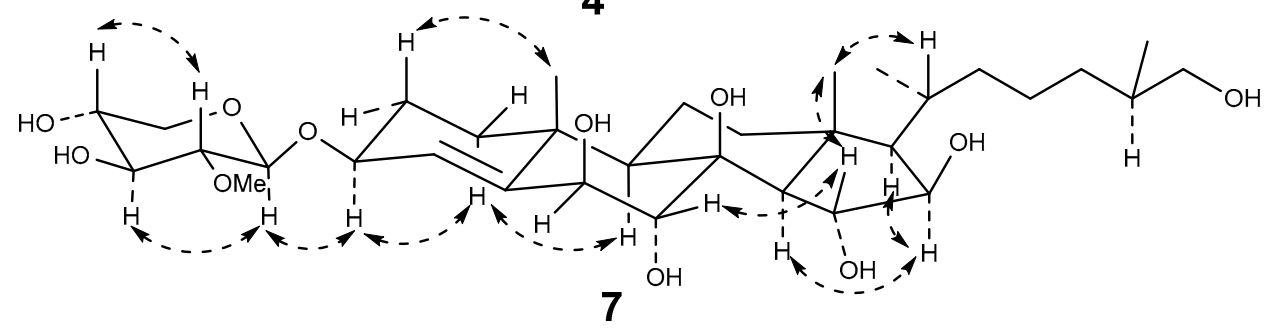

Figure 3. The key NOESY correlations of the new compounds culcinosides A-D (1, 2, 4, and 7).

Culcinoside C (4), a colorless powder, was positive for the Liebermann-Burchard and Molisch tests, which indicated that it might be a steroidal glycoside. The HRESIMS at $m / z 663.3696[\mathrm{M}+\mathrm{Na}]^{+}$ (calculated for $\mathrm{C}_{34} \mathrm{H}_{56} \mathrm{O}_{11} \mathrm{Na}, 663.3720$ ) indicated that the molecular formula of 4 was $\mathrm{C}_{34} \mathrm{H}_{56} \mathrm{O}_{11}$. The ${ }^{1} \mathrm{H},{ }^{13} \mathrm{C}$, and DEPT NMR spectra revealed two double bonds, including one trisubstituted 
double bond $\left(\delta_{\mathrm{C}} 130.3, \delta_{\mathrm{H}} 5.70, \mathrm{C}-4 ; \delta_{\mathrm{C}} 145.4, \mathrm{C}-5\right)$ and one terminal double bond $\left(\delta_{\mathrm{C}} 154.0, \mathrm{C}-28\right.$; $\left.\delta_{\mathrm{C}} 109.4, \delta_{\mathrm{H}} 4.77,4.84\right)$, one anomeric carbon $\left(\delta_{\mathrm{C}} 104.7\right.$ with $\left.\delta_{\mathrm{H}} 4.44\right)$, two angular methyl $\left(\delta_{\mathrm{C}} 17.0\right.$, $\left.\delta_{\mathrm{H}} 1.16 \mathrm{~s}, \mathrm{CH}_{3}-18 ; \delta_{\mathrm{C}} 23.2, \delta_{\mathrm{H}} 1.34 \mathrm{~s}, \mathrm{CH}_{3}-19\right)$, one hydroxymethyl $\left(\delta_{\mathrm{C}} 67.6, \delta_{\mathrm{H}} 3.38,3.59\right)$, five oxygenated methines $\left(\delta_{\mathrm{C}} 77.5, \delta_{\mathrm{H}} 4.24, \mathrm{C}-3 ; \delta_{\mathrm{C}} 79.9, \delta_{\mathrm{H}} 4.13, \mathrm{C}-6 ; \delta_{\mathrm{C}} 73.9, \delta_{\mathrm{H}} 3.98, \mathrm{C}-7 ; \delta_{\mathrm{C}} 80.1\right.$, $\delta_{\mathrm{H}} 4.20, \mathrm{C}-15$; and $\left.\delta_{\mathrm{C}} 82.6, \delta_{\mathrm{H}} 4.03, \mathrm{C}-16\right)$, and one oxygenated quaternary carbon $\left(\delta_{\mathrm{C}} 78.0, \mathrm{C}-8\right)$. All of the chemical shifts belonging to compound 4 were similar to those of the known compound linckoside F (5) from the starfish Linckia laevigata [10]. A detailed comparison of the NMR spectra for compounds 4 and 5 indicated that the only difference was that one methylene $\left(\delta_{\mathrm{C}} 44.6, \delta_{\mathrm{H}} 2.04,3.39\right.$, $\left.\mathrm{CH}_{2}-7\right)$ in 5 was replaced by an oxygenated methine in $4\left(\delta_{\mathrm{C}} 73.9, \delta_{\mathrm{H}} 3.98, \mathrm{CH}-7\right)$. The assignments of the NMR signals associated with compound 4 were derived from the HSQC, ${ }^{1} \mathrm{H}-{ }^{1} \mathrm{H}$ COSY, HMBC, and TOCSY experiments (Table 1). The NOESY correlation for H-7 to H-15 and $\mathrm{H}-18$ to $\mathrm{H}-15$ suggested the $\alpha$ orientation of $\mathrm{C}-7$ (Figure 3 ). The 20R configuration was deduced from the NOESY correlation of H-18 to H-20, and the chemical shift of $\mathrm{H}-21 \delta_{\mathrm{H}} 0.96\left(\delta_{\mathrm{H}} 0.90-0.96\right.$ for $20 R$ steroid). The stereochemistry at C-25 was expected as $S$ by analogy with co-occurring compound 5 , and on the basis of the comparison of their NMR spectra. Thus, the structure of 4 was established as (25S)-3-O-(2-O-methyl- $\beta$-D-xylopyranosyl)-cholesta-4,24(28)-diene-3 $\beta, 6 \beta, 7 \alpha, 8,15 \alpha, 16 \beta, 26$-heptaol.

Culcinoside D (7) was obtained as a colorless powder. The positive results of the Liebermann-Burchard and Molisch tests suggested that it might be a steroidal glycoside. The molecular formula was determined as $\mathrm{C}_{33} \mathrm{H}_{56} \mathrm{O}_{11}$ by HRESIMS at $m / z 651.3740[\mathrm{M}+\mathrm{Na}]^{+}$(calculated for $\left.\mathrm{C}_{33} \mathrm{H}_{56} \mathrm{O}_{11} \mathrm{Na}, 651.3720\right)$. The ${ }^{1} \mathrm{H}-\mathrm{NMR},{ }^{13} \mathrm{C}-\mathrm{NMR}$, and DEPT spectra of compound 7 revealed the presence of a steroidal aglycone with two angular methyls $\left(\delta_{\mathrm{C}} 17.6, \delta_{\mathrm{H}} 1.77, \mathrm{CH}_{3}-18 ; \delta_{\mathrm{C}} 23.6\right.$, $\left.\delta_{\mathrm{H}} 1.68, \mathrm{CH}_{3}-19\right)$, one $4(5)$ double bond $\left(\delta_{\mathrm{C}} 129.8, \delta_{\mathrm{H}} 6.17, \mathrm{C}-4 ; \delta_{\mathrm{C}} 146.2, \mathrm{C}-5\right)$, five oxygenated methine groups $\left(\delta_{\mathrm{C}} 76.6, \delta_{\mathrm{H}} 4.51, \mathrm{C}-3 ; \delta_{\mathrm{C}} 80.0, \delta_{\mathrm{H}} 4.87, \mathrm{C}-6 ; \delta_{\mathrm{C}} 74.5, \delta_{\mathrm{H}} 4.84, \mathrm{C}-7 ; \delta_{\mathrm{C}} 80.4\right.$, $\left.\delta_{\mathrm{H}} 5.11, \mathrm{C}-15 ; \delta_{\mathrm{C}} 82.5, \delta_{\mathrm{H}} 4.72, \mathrm{C}-16\right)$, and a quaternary carbon $\left(\delta_{\mathrm{C}} 78.1, \mathrm{C}-8\right)$ bearing a hydroxy group. The anomeric carbon $\left(\delta_{\mathrm{C}} 104.7\right)$ with $\delta_{\mathrm{H}}$ at $4.76(\mathrm{~d}, 7.6)$ indicated the presence of the common 2-O-methyl- $\beta$-D-xylopyranosyl moiety, and their ${ }^{1} \mathrm{H}$ and ${ }^{13} \mathrm{C}$ signals were assigned by the 2D NMR data (Table 1). The only difference between compounds 7 and 3 , which was elucidated as echinasteroside $\mathrm{C}$ isolated from the starfish Echinaster brasiliensis, was that a methylene $\left(\delta_{\mathrm{C}} 45.0, \delta_{\mathrm{H}} 2.10\right.$ and $\left.3.45, \mathrm{CH}_{2}-7\right)$ in compound 3 was substituted by one oxygenated methine $\left(\delta_{\mathrm{C}} 74.5, \delta_{\mathrm{H}} 4.84, \mathrm{CH}-7\right)$ in compound 7 [20]. Therefore, the structure of 7 was elucidated as (25S)-3-O-(2-O-methyl- $\beta$-D-xylopyranosyl)-cholesta-4-ene-3 $\beta, 6 \beta, 7 \alpha, 8,15 \alpha, 16 \beta, 26$-heptaol.

\subsection{Cytotoxic Activities}

The cytotoxic activity of the new compounds 1, 2, 4, and 7 against human glioblastoma cell lines U87, U251, and SHG44 were evaluated using the 3-(4,5-dimethylthiazol-2-yl)-2,5-diphenyltetrazolium bromide (MTT) colorimetric assay method in vitro [24]. Compound $\mathbf{1}$ exhibited cytotoxicity against the three cancer cell lines, and compounds 2, 4, and 7 showed moderate activity (Table 2). Doxorubicin was used as the positive control.

Table 2. Cytotoxic activity of the new compounds in vitro (mean $\pm \mathrm{SD}, n=3$ ).

\begin{tabular}{cccc}
\hline \multirow{2}{*}{ Compounds } & \multicolumn{3}{c}{ Cytotoxic Activity $\left(\mathrm{IC}_{\mathbf{5 0}, \boldsymbol{\mu M})}\right.$} \\
\cline { 2 - 4 } & U87 & U251 & SHG44 \\
\hline $\mathbf{1}$ & $9.35 \pm 0.46$ & $11.28 \pm 0.65$ & $8.04 \pm 0.32$ \\
$\mathbf{2}$ & $33.52 \pm 1.23$ & $40.76 \pm 1.58$ & $36.54 \pm 1.44$ \\
$\mathbf{4}$ & $26.33 \pm 1.16$ & $22.66 \pm 1.28$ & $35.26 \pm 1.51$ \\
$\mathbf{7}$ & $43.25 \pm 1.73$ & $28.93 \pm 1.83$ & $26.22 \pm 1.64$ \\
Doxorubicin & $0.33 \pm 0.02$ & $0.24 \pm 0.01$ & $0.15 \pm 0.01$ \\
\hline
\end{tabular}




\section{Experimental Section}

\subsection{General Experimental Procedures}

Optical rotations were measured with a Perkin-Elmer 343 polarimeter (German Perkin-Elmer Corporation, Boelingen, Germany). 1D and 2D NMR spectra were recorded on a Bruker AVANCE III 500 and $800 \mathrm{MHz}$ spectrometer with TMS (Tetramethylsilane) as the internal standard. ESIMS and HRESIMS were carried out on a Micromass Quattro mass spectrometer (Waters, Shanghai, China). HPLC was carried out on a Dionex P680 liquid chromatograph (Dionex, Germering, Germany) equipped with a UV $170 \mathrm{UV} /$ Vis detector using a YMC-Pack C18 column $(20 \times 250 \mathrm{~mm}$ i.d., $5 \mu \mathrm{m}$, YMC Co., Ltd., Kyoto, Japan) and monitored at $206 \mathrm{~nm}, 225 \mathrm{~nm}, 275 \mathrm{~nm}$, and $300 \mathrm{~nm}$, simultaneously. GC was performed on a Finnigan Voyager apparatus using an 1-Chirasil-Val column $(25 \mathrm{~m} \times 0.32 \mathrm{~mm}$ i.d.) for the analyses of the trimethylsilyated hydrolysates. Column chromatographies were performed on silica gel (200-300 mesh and 300-400 mesh; Qingdao Marine Chemical Inc., Qingdao, China), reversed phase silica gel (Lichroprep RP-18, 40-63 $\mu \mathrm{m}$, Merck Inc., New York, NY, USA), and Sephadex LH-20 (40-70 $\mu \mathrm{m}$, GE-Healthcare, Uppsala, Sweden). Chemical reagents for isolation were of analytical grade, and purchased from Tianjin Fuyu Chemical Co. Ltd. (Tianjin, China).

\subsection{Animal Material}

The starfish were collected from the South China Sea (Xisha Islands, Sansha, Hainan Province, China) in August 2015. The organisms were identified as Culcita novaeguineae by Dr. Ning Xiao (Institute of Oceanology, Chinese Academy of Science, Qingdao, China). A voucher specimen (No. HX201508) was deposited in the Institute of Materia Medica, School of Pharmacy, Fourth Military Medical University (Xi'an, China).

\subsection{Extraction and Isolation}

The starfish ( $80.0 \mathrm{~kg}$, wet weight) were cut into pieces, and then extracted with $75 \%$ ethanol three times, each time for $2 \mathrm{~h}$ under reflux. The extract was combined and dried in vacuo to leave a residue, which was suspended in water and then partitioned with petroleum ether and $n$-butanol sequentially. The $n$-butanol part $(320.0 \mathrm{~g})$ was subjected to silica gel column chromatography eluting with a $\mathrm{CHCl}_{3} / \mathrm{CH}_{3} \mathrm{OH} / \mathrm{H}_{2} \mathrm{O}$ (50:1:0 to 6:3.5:1) gradient to give 16 major fractions, which were obtained based on TLC analysis. Fraction 10 was subjected to size exclusion chromatography on a Sephadex LH-20 column eluting with $\mathrm{CHCl}_{3} / \mathrm{CH}_{3} \mathrm{OH}$ (1:1) to remove the impurities, then was further purified by HPLC to give compounds $1\left(3.4 \mathrm{mg}, t_{\mathrm{R}}=35.5 \mathrm{~min}\right)$ and $\mathbf{2}\left(1.6 \mathrm{mg}, t_{\mathrm{R}}=57.6 \mathrm{~min}\right)$, eluting with $\mathrm{CH}_{3} \mathrm{CN} / \mathrm{H}_{2} \mathrm{O}(2: 3)$ at a flow rate of $6 \mathrm{~mL} / \mathrm{min}$. $\mathrm{RP}^{-\mathrm{C}_{18}}$ column chromatography eluted with $\mathrm{CH}_{3} \mathrm{OH}: \mathrm{H}_{2} \mathrm{O}$ (1:1 to 1:0) and Sephadex LH-20 column chromatography equilibrated with $\mathrm{CHCl}_{3} / \mathrm{CH}_{3} \mathrm{OH}$ (1:1) were used successively on the purification of fraction 11 to obtain the subfraction fr.11-2-4. Finally, fraction 11-2-4 was subjected to HPLC eluting with $\mathrm{CH}_{3} \mathrm{CN} / \mathrm{H}_{2} \mathrm{O}$ (1:1.5) to afford compounds $3\left(57.1 \mathrm{mg}, t_{\mathrm{R}}=25.6 \mathrm{~min}\right), 4\left(57.2 \mathrm{mg}, t_{\mathrm{R}}=27.3 \mathrm{~min}\right)$, and $5\left(141.3 \mathrm{mg}, t_{\mathrm{R}}=29.3 \mathrm{~min}\right)$. Fraction $12(6.1 \mathrm{~g})$ was subjected to size exclusion chromatography on a Sephadex LH-20 column equilibrated with $\mathrm{CHCl}_{3} / \mathrm{CH}_{3} \mathrm{OH}$ (1:1) to remove impurities and give three subfractions (Fr.12-1 to Fr.12-3). The subfraction 12-2 (2.2 g) was purified by a $\mathrm{RP}^{-\mathrm{C}_{18}}$ column chromatography eluting with $\mathrm{CH}_{3} \mathrm{OH}: \mathrm{H}_{2} \mathrm{O}$ (3:2 to 1:0) to give 10 subfractions. Then, fraction $12-2-8(150.0 \mathrm{mg})$ was purified by semi-preparative HPLC eluting with $\mathrm{CH}_{3} \mathrm{CN} / \mathrm{H}_{2} \mathrm{O}(2: 3)$ at a flow rate of $6 \mathrm{~mL} / \mathrm{min}$ to yield compound $6\left(54.0 \mathrm{mg}, t_{\mathrm{R}}=27.2 \mathrm{~min}\right)$. Compound $7\left(26.6 \mathrm{mg}, t_{\mathrm{R}}=33.0 \mathrm{~min}\right)$ was obtained from fraction $12-2-9$ by HPLC eluting with $\mathrm{CH}_{3} \mathrm{CN} / \mathrm{H}_{2} \mathrm{O}(2: 3)$ at a flow rate of $6 \mathrm{~mL} / \mathrm{min}$.

\subsection{Spectral and Physicochemical Data of New Compounds}

Culcinoside A (1): $\mathrm{C}_{34} \mathrm{H}_{58} \mathrm{O}_{10}$, colorless powder, $[\alpha]_{D}^{22}-13.6(c 0.03, \mathrm{MeOH}),{ }^{1} \mathrm{H}$ - and ${ }^{13} \mathrm{C}-\mathrm{NMR}$ data are shown in Table 1; ESIMS $m / z 649[\mathrm{M}+\mathrm{Na}]^{+} ;$HRESIMS $m / z 649.3942[\mathrm{M}+\mathrm{Na}]^{+}$(calculated for $\left.\mathrm{C}_{34} \mathrm{H}_{58} \mathrm{O}_{10} \mathrm{Na}, 649.3928\right)$. 
Culcinoside B (2): $\mathrm{C}_{34} \mathrm{H}_{56} \mathrm{O}_{10}$, colorless powder, $\left.[\alpha]\right]_{D}^{22}-10.3$ (c 0.04, MeOH), ${ }^{1} \mathrm{H}$ - and ${ }^{13} \mathrm{C}-\mathrm{NMR}$ data are shown in Table 1; ESIMS $m / z 647[\mathrm{M}+\mathrm{Na}]^{+} ;$HRESIMS $m / z 647.3795[\mathrm{M}+\mathrm{Na}]^{+}$(calculated for $\mathrm{C}_{34} \mathrm{H}_{56} \mathrm{O}_{10} \mathrm{Na}$ 647.3771).

Culcinoside $\mathrm{C}$ (4): $\mathrm{C}_{34} \mathrm{H}_{56} \mathrm{O}_{11}$, colorless powder, $\left.[\alpha]\right]_{D}^{22}-28.4$ (c $\left.0.21, \mathrm{MeOH}\right),{ }^{1} \mathrm{H}$ - and ${ }^{13} \mathrm{C}-\mathrm{NMR}$ data are shown in Table 1; ESIMS $m / z 663[\mathrm{M}+\mathrm{Na}]^{+} ;$HRESIMS $m / z 663.3696[\mathrm{M}+\mathrm{Na}]^{+}$(calculated for $\mathrm{C}_{34} \mathrm{H}_{56} \mathrm{O}_{11} \mathrm{Na}$ 663.3720).

Culcinoside D (7): $\mathrm{C}_{33} \mathrm{H}_{56} \mathrm{O}_{11}$, colorless powder, $[\alpha]_{D}^{22}-16.5$ (c $\left.0.11, \mathrm{MeOH}\right),{ }^{1} \mathrm{H}$ - and ${ }^{13} \mathrm{C}-\mathrm{NMR}$ data are shown in Table 1; ESIMS $m / z 651[\mathrm{M}+\mathrm{Na}]^{+} ;$HRESIMS $m / z 651.3740[\mathrm{M}+\mathrm{Na}]^{+}$(calculated for $\mathrm{C}_{33} \mathrm{H}_{56} \mathrm{O}_{11} \mathrm{Na}$, 651.3720).

\subsection{Demethylation and Acid Hydrolysis of the New Compounds}

The new compounds (each $1.5 \mathrm{mg}$ ) were mixed with $1 \mathrm{~mL}$ of dry dichloromethane and $0.01 \mathrm{~mL}$ of boron tribromide at $-80^{\circ} \mathrm{C}$ for $30 \mathrm{~min}$, and then stood overnight at $10^{\circ} \mathrm{C}$ under anhydrous conditions. The solvent and reagent were evaporated to dryness in vacuo at room temperature. The demethylated derivative of the new compound was heated with $1.0 \mathrm{~mL}$ of trifluoroacetic acid (TFA) at $120^{\circ} \mathrm{C}$ for $2 \mathrm{~h}$. The reaction mixture was evaporated in vacuo, and the residue was partitioned between $\mathrm{CH}_{2} \mathrm{Cl}_{2}$ and $\mathrm{H}_{2} \mathrm{O}$. The aqueous phase was concentrated and dissolved in 1-(trimethylsilyl)imidazole and anhydrous pyridine $(0.1 \mathrm{~mL})$. Then, the solution was stirred at $60^{\circ} \mathrm{C}$ for $5 \mathrm{~min}$, and dried with a stream of $\mathrm{N}_{2}$. The residue was partitioned between $\mathrm{CH}_{2} \mathrm{Cl}_{2}$ and $\mathrm{H}_{2} \mathrm{O}$. The $\mathrm{CH}_{2} \mathrm{Cl}_{2}$ layer was analyzed by $\mathrm{GC}$ with an initial temperature of $100{ }^{\circ} \mathrm{C}$ for $1 \mathrm{~min}$, and then temperature programmed to $180^{\circ} \mathrm{C}$ at a rate of $5{ }^{\circ} \mathrm{C} / \mathrm{min}$. The peak of the derivative of the sample was detected at 11.25 and $12.46 \mathrm{~min}$ for compound 1, 11.25 and $12.45 \mathrm{~min}$ for compound 2, 11.23 and 12.45 for compound 4, and 11.24 and $12.26 \mathrm{~min}$ for compound 7. The retention time of the authentic samples after being treated simultaneously with 1-(trimethylsily)imidazole in pyridine were 11.23 and $12.44 \mathrm{~min}$ (D-xylose), and 11.34 and $12.40 \mathrm{~min}$ (L-xylose), respectively [6].

\subsection{Assays for In Vitro Cytotoxicity}

The cytotoxicity of new compounds 1, 2, 4, and 7 against human glioblastoma cell lines U87, U251, and SHG44 were evaluated by the 3-(4,5-dimethylthiazol-2-yl)-2,5-diphenyltetrazolium bromide (MTT) colorimetric assay method in vitro. All of the cells were cultured in RPMI-1640 medium supplemented with $10 \%$ fetal bovine serum, $100 \mathrm{U} / \mathrm{mL}$ benzyl penicillin, and $100 \mathrm{U} / \mathrm{mL}$ streptomycin at $37{ }^{\circ} \mathrm{C}$ in a humidified atmosphere with $5 \% \mathrm{CO}_{2}$. The logarithmic phase cells were seeded on 96-well plates at a concentration of $4 \times 10^{3} \mathrm{cell} / \mathrm{mL}$, and incubated with various concentrations $(100 \mu \mathrm{M}, 80 \mu \mathrm{M}, 60 \mu \mathrm{M}, 40 \mu \mathrm{M}, 20 \mu \mathrm{M}, 10 \mu \mathrm{M}, 1 \mu \mathrm{M}$, and $0.25 \mu \mathrm{M}$ in medium containing less than $0.1 \%$ DMSO) of test compounds in triple wells for $48 \mathrm{~h}$, and doxorubicin was used as the positive control. Next, $20 \mu \mathrm{L}$ MTT $(5 \mathrm{mg} / \mathrm{mL})$ was added to each well, and incubated for another $4 \mathrm{~h}$. The water-insoluble dark blue formazan crystals formed during MTT cleavage in actively metabolizing cells were dissolved in DMSO. The optical density of each well was measured with a Bio-Rad 680 microplate reader at $570 \mathrm{~nm}$. Cytotoxicity was expressed as the concentration of drug inhibiting cell growth by $50 \%\left(\mathrm{IC}_{50}\right)$.

Supplementary Materials: The NMR and HRESIMS data of the new compounds and the ${ }^{13} \mathrm{C}-\mathrm{NMR}$ data of the known compounds are available online at www.mdpi.com/1660-3397/16/3/92/s1.

Acknowledgments: This research was financially supported by the National Nature Science Foundation of China (No. 81473132).

Author Contributions: The listed authors contributed to this work as described in the following. Y.L., H.L., and Y.L. carried out the extraction and isolation. Y.L. also collected the organism of Culcita novaeguineae and participated in the structural elucidation. M.W. and K.L. participated in the structural elucidation. Y.F. conducted the MTT colorimetric assay and helped interpret the results. Corresponding author H.T. organized the study and participated in the structural elucidation. All authors helped prepare the manuscript and approved the final version. 
Conflicts of Interest: The authors declare no conflict of interest.

\section{Abbreviations}

The following abbreviations are used in this paper:

$\begin{array}{ll}\text { DEPT } & \text { Distortionless enhancement by polarization transfer } \\ \text { ESIMS } & \text { Electron spray ionization mass spectrum } \\ { }^{1} \mathrm{H}-{ }^{1} \mathrm{H} \text { COSY } & { }^{1} \mathrm{H}-{ }^{1} \mathrm{H} \text { Correlation spectroscopy } \\ \mathrm{HMBC} & { }^{1} \mathrm{H} \text {-detected heteronuclear multiple bond correlation } \\ \text { HPLC } & \text { High performance liquid chromatography } \\ \text { HRESIMS } & \text { High resolution electron spray ionization mass spectrum } \\ \text { HSQC } & { }^{1} \mathrm{H} \text {-detected heteronuclear single quantum correlation } \\ \text { NMR } & \text { Nuclear magnetic resonance } \\ \text { NOESY } & \text { Nuclear overhauser enhancement spectroscopy } \\ \text { TLC } & \text { Thin layer chromatography } \\ \text { TOCSY } & \text { Total correlation spectroscopy }\end{array}$

\section{References}

1. Mah, C.L.; Blake, D.B. Global diversity and phylogeny of the Asteroidea (Echinodermata). PLoS ONE 2012, 7, e35644. [CrossRef] [PubMed]

2. Tang, H.; Yi, Y.; Li, L.; Sun, P. Bioactive asterosaponins from the starfish Culcita novaeguineae. J. Nat. Prod. 2005, 68, 337-341. [CrossRef] [PubMed]

3. Kicha, A.A.; Ivanchina, N.V.; Kalinovsky, A.I.; Dmitrenok, P.S.; Stonik, V.A. Steroidal monoglycosides from the Far Eastern starfish Hippasteria kurilensis and hypothetic pathways of polyhydroxysteroid biosynthesis in starfish. Steroids 2009, 74, 238-244. [CrossRef] [PubMed]

4. $\quad$ Blunt, J.W.; Copp, B.R.; Keyzers, R.A.; Munro, M.H.G.; Prinsep, M.R. Marine natural products. Nat. Prod. Rep. 2015, 32, 116-211. [CrossRef] [PubMed]

5. Mayer, A.M.S.; Rodríguez, A.D.; Taglialatela-Scafati, O.; Fusetani, N. Marine pharmacology in 2009-2011: Marine compounds with antibacterial, antidiabetic, antifungal, anti-inflammatory, antiprotozoal, antituberculosis, and antiviral activities; affecting the immune and nervous systems, and other miscellaneous mechanisms of Action. Mar. Drugs 2013, 11, 2510-2573. [PubMed]

6. Ma, N.; Tang, H.F.; Qiu, F.; Lin, H.W.; Tian, X.R.; Yao, M.N. Polyhydroxysteroidal glycosides from the starfish anthenea chinensis. J. Nat. Prod. 2010, 73, 590-597. [CrossRef] [PubMed]

7. Ivanchina, N.V.; Kicha, A.A.; Stonik, V.A. Steroid glycosides from marine organisms. Steroids 2011, 76, 425-454. [CrossRef] [PubMed]

8. Kang, J.X.; Kang, Y.F.; Han, H. Three New Cytotoxic Polyhydroxysteroidal Glycosides from Starfish Craspidaster hesperus. Mar. Drugs 2016, 14, 189. [CrossRef] [PubMed]

9. Malyarenko, T.V.; Kharchenko, S.D.; Kicha, A.A.; Ivanchina, N.V.; Dmitrenok, P.S.; Chingizova, E.A.; Pislyagin, E.A.; Evtushenko, E.V.; Antokhina, T.I.; Van Minh, C.; et al. Anthenosides L-U, Steroidal Glycosides with Unusual Structural Features from the Starfish Anthenea aspera. J. Nat. Prod. 2016, 79, 3047-3056. [CrossRef] [PubMed]

10. Han, C.; Qi, J.; Ojika, M. Structure-activity relationships of novel neuritogenic steroid glycosides from the Okinawan starfish Linckia laevigata. Bioorg. Med. Chem. 2006, 14, 4458-4465. [CrossRef] [PubMed]

11. Qi, J.; Ojika, M.; Sakagami, Y. Linckosides A and B, two new neuritogenic steroid glycosides from the Okinawan starfish Linckia laevigata. Bioorg. Med. Chem. 2002, 10, 1961-1966. [CrossRef]

12. Kicha, A.A.; Ivanchina, N.V.; Kalinovsky, A.I.; Dmitrenok, P.S.; Sokolova, E.V.; Agafonova, I.G.; Morre, J.; Stonik, V.A. Four new steroid glycosides from the Vietnamese starfish Linckia laevigata. Russ. Chem. Bull. 2007, 56, 823-830. [CrossRef]

13. Guan, H.S.; Wang, S.G. Chinese Marine Herbal; Shanghai Science and Technology Press: Shanghai, China, 2009; Volume 3, pp. 608-610. 
14. Ngoan, B.T.; Hanh, T.T.H.; Vien, L.T.; Diep, C.N.; Thao, N.P.; Thao, D.T.; Van Thanh, N.; Cuong, N.X.; Nam, N.H.; Thung, D.C.; et al. Asterosaponins and glycosylated polyhydroxysteroids from the starfish Culcita novaeguineae and their cytotoxic activities. J. Asian Nat. Prod. Res. 2015, 17, 1010-1017. [CrossRef] [PubMed]

15. Iorizzi, M.; Minale, L.; Riccio, R.; Higa, T.; Tanaka, J. Starfish saponins, Part $46 .{ }^{1}$ Steroidal glycosides and polyhydroxysteroids from the starfish Culcita novaeguineae. J. Nat. Prod. 1991, 54, 1254-1264. [CrossRef] [PubMed]

16. Tang, H.F.; Yi, Y.H.; Li, L.; Sun, P.; Zhang, S.Q.; Zhao, Y.P. Asterosaponins from the starfish Culcita novaeguineae and their bioactivities. Fitoterapia 2006, 77, 28-34. [CrossRef] [PubMed]

17. Tang, H.F.; Cheng, G.; Wu, J.; Chen, X.L.; Zhang, S.Y.; Wen, A.D.; Lin, H.W. Cytotoxic asterosaponins capable of promoting polymerization of tubulin from the starfish Culcita novaeguineae. J. Nat. Prod. 2009, 72, 284-289. [CrossRef] [PubMed]

18. Tang, H.F.; Yi, Y.H.; Li, L.; Sun, P.; Zhang, S.Q.; Zhao, Y.P. Three New Asterosaponins from the Starfish Culcita novaeguineae and their Bioactivity. Planta Med. 2005, 71, 458-463. [CrossRef] [PubMed]

19. Cheng, G.; Zhang, X.; Tang, H.F.; Zhang, Y.; Zhang, X.H.; Cao, W.D.; Gao, D.K.; Wang, X.L.; Jin, B.Q. Asterosaponin 1, a cytostatic compound from the starfish Culcita novaeguineae, functions by inducing apoptosis in human glioblastoma U87MG cells. J. Neurooncol. 2006, 79, 235-241. [CrossRef] [PubMed]

20. Iorizzi, M.; de Riccardis, F.; Minale, L.; Riccio, R. Starfish saponins, 52. Chemical constituents from the starfish echinaster brasiliensis. J. Nat. Prod. 1993, 56, 2149-2162. [CrossRef] [PubMed]

21. Kicha, A.A.; Ivanchina, N.V.; Kalinovsky, A.I.; Dmitrenok, P.S.; Smirnov, A.V. Two New Steroid Glycosides from the Far East Starfish Hippasteria kurilensis. Russ. J. Bioorg. Chem. 2009, 35, 504-509. [CrossRef]

22. Zhu, D.; Yu, B. Total Synthesis of Linckosides A and B, the Representative Starfish Polyhydroxysteroid Glycosides with Neuritogenic Activities. J. Am. Chem. Soc. 2015, 137, 15098-15101. [CrossRef] [PubMed]

23. Malyarenko, T.V.; Kicha, A.A.; Kalinovsky, A.I.; Ivanchina, N.V.; Popov, R.S.; Pislyagin, E.A.; Menchinskaya, E.S.; Padmakumar, K.P.; Stonik, V.A. Four New Steroidal Glycosides, Protolinckiosides A-D, from the Starfish Protoreaster lincki. Chem. Biodivers. 2016, 998-1007. [CrossRef] [PubMed]

24. Alley, M.C.; Scudiero, D.A.; Monks, A.; Hursey, M.L.; Czerwinski, M.J.; Fine, D.L.; Abbott, B.J.; Mayo, J.G.; Shoemaker, R.H.; Boyd, M.R. Feasibility of drug screening with panels of human tumor cell lines using a microculture tetrazolium assay. Cancer Res. 1988, 48, 589-601. [PubMed] 